\title{
Raised crosswalks efficacy on the lowering of vehicle speeds
}

\author{
A. Pratelli, R. Pratali \& M. Rossi \\ Dipartimento di Ingegneria Civile "Vie e Trasporti", \\ University of Pisa, Italy
}

\begin{abstract}
A road hump, or speed hump, is a traffic calming device used to reduce vehicle speed and volume on residential streets. Road humps are placed across the road to slow traffic and are often installed in a series of several humps in order to prevent cars from speeding before and after the hump. Speed humps are used in locations where very low speeds are desired and reasonable. Speed humps are typically placed on residential roads and are not used on major roads, bus routes, or primary emergency response routes. In Italy, the road humps are often built in the shape of raised crosswalks, or RCWs, and they are generally placed both close and between intersections.

This paper deals with the analysis of observed data on a large sample of RCWs located in Tuscany, central Italy. Such data were referred both to geometry characteristics of the single raised crosswalk and recorded differences in vehicle speeds before and after it. Speed data were gathered using two automatic radar-recorders for each one of the sampled raised crosswalks.

All the collected data were analyzed through statistical tests in order to assess their homogeneity or not between different locations and various types of roads. Finally, we were able to make some conclusions and highlight design aspects. On one side, RCWs with similar geometries and higher heights (about $15 \mathrm{~cm}$ ) have similar effects on vehicle speed lowering, regardless of local conditions (location, road geometry, driver behaviour, etc.).

Moreover, raised crosswalks installed in a series have a stronger efficacy than the isolated ones. On the opposite side, the effects of raised crosswalks with smaller heights (less than $6 \mathrm{~cm}$ ) show clearly a very low influence on vehicle speed variations.
\end{abstract}

Keywords: road humps, raised crosswalks series, speed lowering, traffic calming devices. 


\section{Introduction}

Since the 60s, various European cities have been advised of the need to restore to the citizens those portions of the town which had gradually been invaded by vehicular traffic using various techniques of traffic calming. In Italy the interest in traffic calming techniques has experienced a notable increase since the $90 \mathrm{~s}$.

If we wanted to give a definition of traffic calming, we could say that this is a combination of interventions, mainly physical, aimed at reducing the negative effects arising from the use of motor vehicles in those areas where such effects are a source of a security's reduction for non-motorized users of the road.

One of the purposes of traffic calming priority is therefore to provide benefits for the typically residential environmental hitting directly the grounds of hardship caused by vehicular traffic: traffic volumes and vehicle speeds [1].

The reduced security of urban roads is, in fact, attributable mainly to two reasons:

- The first, of a psychological nature, related to the fact that every road is itself a place intended for the use of vehicles: in consequence, vehicle drivers consider it their right to pursue a superiority over other road users (such as pedestrians and cyclists). In addition, each type of user has, in practice, the freedom to take the behaviour they want.

- The second, of a physical nature, linked to wrong urban planning and forecasts of growth in demand for mobility: as a result of this, high traffic volumes are in transit, often at high speeds in residential areas that do not have sufficient capacity to bear.

In those circumstances, the objectives arising from traffic calming are:

- To improve the safety of some types of road users and the quality of life of residents.

- To ensure good accessibility to these residential areas.

- To improve the conditions of local roads, which will still continue to support heavy traffic.

One of the ways to achieve these goals is to use physical constraints, or "elements of traffic calming", or else the adoption of infrastructure devices able to give significant reductions in speed for drivers of motor vehicles and therefore able to improve the road safety for all users [2]. Overall, these devices include both types here considered, raised crosswalks (or RCWs) and road humps.

\section{Devices}

\subsection{Raised crosswalks (RCWs)}

The raised crosswalk devices, created by the combination of a road hump with a pedestrian crosswalk, consisting of a raising of the roadway with a ramp, is made for the dual purpose of giving continuity to the sidewalks on both sides of the road, and then facilitate the crossing of pedestrians, and to interrupt the continuity of long straights and therefore reduce the speed of vehicles. 
They can be put in place both individually and in series. In this second case, RCWs are installed properly spaced so as to moderate the speed of vehicles over a certain extent of a road, resulting in a further reduction of pollutant emissions as a result of their loss of speed. These devices are particularly effective if carried out in series and spaced each other of 80-120 m.

\subsection{Road humps}

These devices are elements with a convex profile placed on the roadway, whose purpose is to force drivers to reduce speed of their vehicles in the road section in which they are installed.

Like the RCWs, these devices are in fact a discontinuity both visual (break the linearity of the distance) and physical (vehicles must pass a slight height difference).

\subsection{The Australian case}

Some researchers of the Department of Transport Engineering of the University of Sydney wrote in 1997 a paper dealing with the effects of mid-block speed control devices [3]. This quoted work contains some interesting information on the use of such traffic calming devices:

- when flows are greater than $600 \mathrm{veh} / \mathrm{h}$, the increase in travel time over the road on which they are installed is substantial, and increases with increasing traffic volumes;

- the road capacity decreases, and such decrease is more pronounced with the increasing of traffic volumes;

- the opportunity of road crossing for pedestrians, as measured by the parameter of Crossing Opportunities Index (or COI), is reduced and this reduction is more pronounced for the higher volumes of traffic;

- effects of these devices are maximum within 30-50 m from the device and vehicle flows higher than $900 \mathrm{veh} / \mathrm{h}$;

- these devices should be installed at least at $50 \mathrm{~m}$ from the intersections.

\section{Raised crosswalks (RCWs)}

\subsection{Italian and international standards}

Italian guidelines are quite lacking for any recommendation regarding the RCWs geometry and general features.

Therefore one can find poor references to these devices in various documents, but none of them provides to any detailed technical specification or design guideline.

Italian Urban Road Safety Planning guide provides the following definition for RCWs: "Raised road areas or raised crosswalks, speed tables: rising of the roadway by a ramp (with a slope of approximately $10 \%$ ) to indicate areas of pedestrian crossing or, however, areas to be protected from high speeds. The 
length affected by the rising generally exceeds that of normal vehicles (10-12 m), otherwise it will be classified as a road hump" [4].

Given the scarcity of information (also about sizing and location of the road humps), it is preferable to treat these special devices as a separate category, because of two reasons as follows:

a) the road humps built in concrete trapezoidal profile (i.e. the only ones suitable for use as pedestrian crossings) can be placed only on roads with speed limits below $30 \mathrm{~km} / \mathrm{h}$. As a result, raised crosswalks could not be implemented on roads with a higher speed limit.

b) the road humps may have a maximum height of $7 \mathrm{~cm}$. This height means that in most cases the continuity of the pavement can be achieved only by lowering significantly the level of the sidewalk at the same crossing. Moreover, experimental measurements have shown that a height of $7 \mathrm{~cm}$ could be not sufficient to induce a vehicle's speed reduction under the achieved speed at pedestrian crossings.

In other countries there is a bit more interest for these devices. Guidelines and standards on their building, sizing and positioning are often provided.

Particular attention is given to the configuration of the ramps connecting the level of the roadway and the platform. These ramps can take different forms: straight (the most commonly used for manufacturing simplicity, functionality and building costs), a parabolic profile, a sinusoidal profile (useful to facilitate the transit of cyclists), height $\mathrm{H}$ and slope $\mathrm{S}$ (the latter characterized by a particular layout, well-suited for promoting the passage of heavy vehicles and public transport).

With regard to the geometric dimensions, there is much uniformity among the various standards. Virtually all agree to retain the slope of the ramps below the $10 \%$, to limit the height of the ramp below $10 \mathrm{~cm}$ (or for the extension of the platform) and the width below $5 \mathrm{~m}$ (local roads), and on road marking to be taken for these devices.

\subsection{Measurements on RCWs}

The devices used for speed detection was a portable Radar Recorder, produced by CA Traffic Ltd. The measurements have been carried out in seven different sites [5], chosen through the following criteria:

a) differences in geometry;

b) adequate distance from any perturbation cause, such as congestion points, intersections, parking lots, and so on;

c) possibility of Radar Recorder positioning (presence of poles close to).

When faced with an isolated RCW, we used a couple of radars, one of which was installed at the RCW and the other at a distance where vehicles do not suffer the calming effect. In case of a RCWs' series, one radar was always positioned in correspondence of the RCW to be measured (in the case of series of 3 or more we always positioned the first radar at the RCW located in the middle) and the other one was in an intermediate position between RCWs.

The main characteristics of the seven stations are shown in Table 1, while Table 2 summarizes the field data collected for each site, and where: 
- $\quad V_{\text {med }}: \quad$ average of the observed speeds by the radar close to the RCW;

- $V_{85}: \quad 85^{\text {th }}$ percentile of the speed distribution close to the RCW;

- $V_{85}{ }^{m}: 85^{\text {th }}$ percentile of the observed speed distribution at the intermediate position, in case of a RCWs' series;

- $\quad V_{\max }$ : maximum of the observed speed value by anyone radar;

Table 1: Observed RCWs' main characteristics [5].

\begin{tabular}{|c|c|c|c|c|c|c|c|c|}
\hline $\begin{array}{c}\text { Location } \\
\text { (city) }\end{array}$ & $\begin{array}{c}\text { Site } \\
\text { ref. }\end{array}$ & $\begin{array}{c}\text { Elements } \\
\text { in RCWs } \\
\text { series }\end{array}$ & $\begin{array}{c}\text { Distance } \\
\text { between } \\
R C W, \\
{[\mathrm{~m}]}\end{array}$ & $\begin{array}{c}H \\
{[\mathrm{~cm}]}\end{array}$ & $\begin{array}{c}L_{\text {platform }} \\
{[\mathrm{m}]}\end{array}$ & $\begin{array}{c}L_{\text {ramp }} \\
{[\mathrm{m}]}\end{array}$ & $\begin{array}{c}\text { Avg. } \\
\text { flow } \\
{[\text { veh/h] }}\end{array}$ & Notes \\
\hline $\begin{array}{c}\text { Via Urbiciani } \\
\text { (Lucca) }\end{array}$ & $\mathrm{A}$ & 2 & 200 & 15 & 3.5 & 2 & 320 & - \\
\hline $\begin{array}{c}\text { Via dei } \\
\text { Cavalletti } \\
\text { (Lucca) }\end{array}$ & $\mathrm{B}$ & 3 & 100 & 15 & 3 & 2.7 & 580 & - \\
\hline $\begin{array}{c}\text { Via Strettoia } \\
\text { (Pietrasanta) }\end{array}$ & $\mathrm{C}$ & 3 & $\begin{array}{c}50 \\
80\end{array}$ & 15 & 3.3 & 2.5 & 180 & - \\
\hline $\begin{array}{c}\text { Via Bernini } \\
\text { (Pietrasanta) }\end{array}$ & $\mathrm{D}$ & 3 & 120 & 15 & 3.3 & 2.5 & 200 & $\begin{array}{c}\text { Cycle } \\
\text { path }\end{array}$ \\
\hline $\begin{array}{c}\text { Via Bonanno } \\
\text { (Pisa) }\end{array}$ & $\mathrm{E}$ & 3 & $\begin{array}{c}150 \\
1500\end{array}$ & 5 & 4.5 & 0.8 & 1150 & - \\
\hline $\begin{array}{c}\text { Viale } \\
\text { Michelangelo } \\
\text { (Pisa) }\end{array}$ & $\mathrm{F}$ & 2 & 150 & 5 & 3.5 & 1.3 & 700 & $\begin{array}{l}\text { Traffic } \\
\text { island }\end{array}$ \\
\hline $\begin{array}{c}\text { Via Vittorio } \\
\text { Veneto } \\
\text { (Pontedera) }\end{array}$ & $\mathrm{G}$ & 2 & 170 & 5 & 4 & 1.2 & 930 & - \\
\hline
\end{tabular}

Table 2: $\quad$ Field measured speeds $[\mathrm{km} / \mathrm{h}]$ in each of seven sites [5].

\begin{tabular}{|c|c|c|c|c|}
\hline Site ref. & $V_{\text {med }}[\mathrm{km} / \mathrm{h}]$ & $V_{85}[\mathrm{~km} / \mathrm{h}]$ & $V_{85}{ }^{m}[\mathrm{~km} / \mathrm{h}]$ & $V_{\max }[\mathrm{km} / \mathrm{h}]$ \\
\hline A & 29 & 33 & 48 & 87 \\
\hline B & 36 & 43 & 45 & 68 \\
\hline C & 35 & 42 & 49 & 58 \\
\hline D & 29 & 39 & 40 & 60 \\
\hline E & 42 & 49 & 51 & 90 \\
\hline F & 36 & 43 & - & 79 \\
\hline G & 37 & 45 & 46 & 69 \\
\hline
\end{tabular}

\subsection{Test results}

It was important of evaluating the efficacy of each type the RCW used in the different sites, and compare among themselves all the data gathered to investigate a possible homogeneity. This also would mean uniformity of effect of the different characteristics of the RCWs. 
Efficacy was assessed using a correlation between the height of RCW and average speed of vehicles measured at the RCW itself, whose results are shown in the chart below (Figure 1).
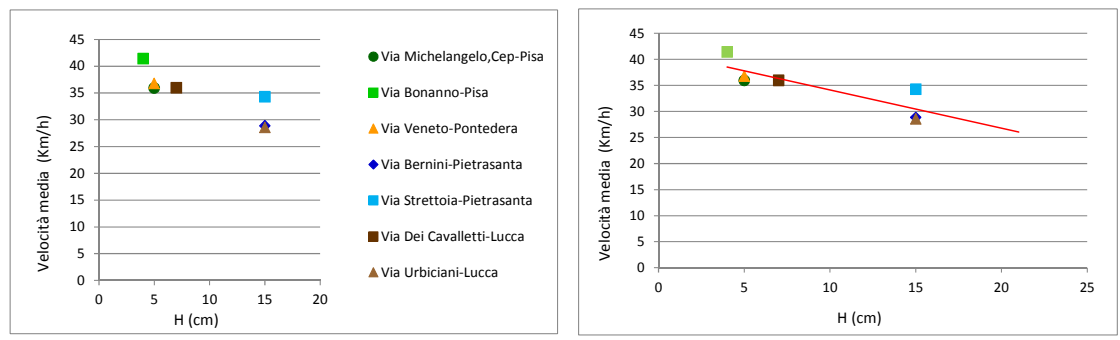

Figure 1: RCW' efficacy on average speed observed at different sites and in respect to different heights.

The comparison between the different samples collected in different sites was conducted using the $F$-test (also known as Fischer test), or test about the homogeneity of variances [6]. This test run the ratio of the variances of two samples, $s_{1}{ }^{2}$ and $s_{2}^{2}$, with $s_{1}{ }^{2}>s_{2}{ }^{2}$ :

$$
F=\frac{s_{1}^{2}}{s_{2}^{2}}
$$

with $v_{1}=n_{1}-1$ and $v_{2}=n_{2}-1$ degrees of freedom of numerator and denominator, where $n_{1}$ and $n_{2}$ are size of the two samples.

Table 1a: $\quad F$-Test results obtained for paired locations of RCWs.

\begin{tabular}{|l|c|c|c|c|c|c|}
\hline \multicolumn{1}{|c|}{$\begin{array}{c}\text { Paired } \\
\text { locations }\end{array}$} & $F$ & v num. & $v$ den. & Fcrit. & $\alpha$ & $\begin{array}{c}H_{0} \\
\text { hypothesis }\end{array}$ \\
\hline Cep-Bonanno & 1.223 & 3555 & 2090 & 1.067 & 0.05 & rejected \\
\hline Cep-V.Veneto & 1.096 & 2889 & 2090 & 1.069 & 0.05 & rejected \\
\hline Cep-Bernini & 1.156 & 2090 & 601 & 1.116 & 0.05 & rejected \\
\hline Cep-Strettoia & 1.218 & 2090 & 521 & 1.123 & 0.05 & rejected \\
\hline Cep-Cavalletti & 1.242 & 2090 & 1938 & 1.076 & 0.05 & rejected \\
\hline Cep-Urbiciani & 1.411 & 2090 & 1065 & 1.092 & 0.05 & rejected \\
\hline $\begin{array}{l}\text { Bonanno- } \\
\text { V.Veneto }\end{array}$ & 1.115 & 3555 & 2889 & 1.060 & 0.05 & rejected \\
\hline $\begin{array}{l}\text { Bonanno- } \\
\text { Bernini }\end{array}$ & 1.414 & 3555 & 601 & 1.111 & 0.05 & rejected \\
\hline
\end{tabular}

The value of $F$ so calculated was then compared with the critical value extracted from the table of $F$-test for a significance level $\alpha=0.05$.

The value of $F$ so calculated was then compared with the critical value extracted from the table of $F$-test for a significance level $\alpha=0.05$.

If the value of $F$ calculated is less than the critical one, then you can accept the assumption of homogeneity of variances and then of the two samples, otherwise such a case should be dismissed. 
The result of the performed $F$-test is shown in Table $3 \mathrm{a}$ and Table $3 \mathrm{~b}$.

Table 3b: $\quad F$-Test results obtained for paired locations of RCWs.

\begin{tabular}{|c|c|c|c|c|c|c|}
\hline $\begin{array}{c}\text { Paired } \\
\text { locations }\end{array}$ & $F$ & $v$ num. & $v$ den. & Fcrit. & $\alpha$ & $\begin{array}{c}H_{0} \\
\text { hypothesis }\end{array}$ \\
\hline $\begin{array}{c}\text { V.Veneto- } \\
\text { Bernini }\end{array}$ & 1.268 & 2889 & 601 & 1.112 & 0.05 & rejected \\
\hline $\begin{array}{c}\text { V.Veneto- } \\
\text { Strettoia }\end{array}$ & 1.335 & 2889 & 521 & 1.120 & 0.05 & rejected \\
\hline $\begin{array}{c}\text { V.Veneto- } \\
\text { Cavalletti }\end{array}$ & 1.362 & 2889 & 1938 & 1.071 & 0.05 & rejected \\
\hline $\begin{array}{c}\text { V.Veneto- } \\
\text { Urbiciani }\end{array}$ & 1.547 & 2889 & 1065 & 1.088 & 0.05 & rejected \\
\hline $\begin{array}{c}\text { Bernini- } \\
\text { Strettoia }\end{array}$ & 1.053 & 601 & 521 & 1.150 & 0.05 & accepted* \\
\hline $\begin{array}{c}\text { Bernini- } \\
\text { Cavalletti }\end{array}$ & 1.074 & 601 & 1938 & 1.113 & 0.05 & accepted* \\
\hline $\begin{array}{c}\text { Bernini- } \\
\text { Urbiciani }\end{array}$ & 1.221 & 601 & 1065 & 1.125 & 0.05 & rejected \\
\hline $\begin{array}{c}\text { Strettoia- } \\
\text { Cavalletti }\end{array}$ & 1.021 & 521 & 1938 & 1.119 & 0.05 & accepted* \\
\hline $\begin{array}{c}\text { Strettoia- } \\
\text { Urbiciani }\end{array}$ & 1.159 & 521 & 1065 & 1.131 & 0.05 & rejected \\
\hline $\begin{array}{c}\text { Cavalletti- } \\
\text { Urbiciani }\end{array}$ & 1.136 & 1938 & 1065 & 1.094 & 0.05 & rejected \\
\hline $\begin{array}{c}\text { Bonanno- } \\
\text { Strettoia }\end{array}$ & 1.489 & 3555 & 521 & 1.118 & 0.05 & rejected \\
\hline $\begin{array}{c}\text { Bonanno- } \\
\text { Cavalletti }\end{array}$ & 1.519 & 3555 & 1938 & 1.068 & 0.05 & rejected \\
\hline $\begin{array}{c}\text { Bonanno- } \\
\text { Urbiciani }\end{array}$ & 1.726 & 3555 & 1065 & 1.086 & 0.05 & rejected \\
\hline
\end{tabular}

As one can see, since the geometry of RCWs of Via Strettoia and Via Bernini is the same, there are two types of RCWs that can be considered homogeneous (Via Bernini-Via Strettoia and Via Cavalletti), so it can be argued that adopting the geometry used on Via Bernini-Via Strettoia or the one used on Via Cavalletti one can obtain the same effects on driver behaviour in lowering speeds.

Then, the data of the three sites that results homogenous can be merged in a single sample which is characterized by the following speed values:

- $\quad V_{\text {med }}=34.28 \mathrm{~km} / \mathrm{h}$

- $\quad V_{85}=41.0 \mathrm{~km} / \mathrm{h}$

- $\quad V_{\max }=68.0 \mathrm{~km} / \mathrm{h}$ 


\section{Road humps}

\subsection{Italian standard}

Italian Road Rule guide [7] sets out the roads where the bumps may be used and provides some technical specifications: "On the roads where the speed limit not exceeding $50 \mathrm{~km} / \mathrm{h}$ you can take road humps [...]. The road humps must be installed only on local streets, public parks, privately-owned residences, etc. Can be installed in series and must be marked. It may not be used on roads that are preferred routes of emergency vehicles" (Article 179, paragraphs 4 - amended by art. 107, DPR 610/1996 - and 5).

Italian Planning for Road Safety guide suggests that road humps can be installed on roads both of Category E (i.e. urban roads) and of Category F (i.e. local roads) and in respect to any daily traffic volumes.

Also art. 179 of the Italian Road Rule contains some technical specifications regarding the road humps and their conditions of use: "4. [The road humps are to be] marked by yellow and black zebra parallel to the direction of the traffic flow, with the same width for both yellow and black signs; must be clearly visible both day and night. [...] 6. The road humps under previous section 4 shall consist of prefabricated plastic elements in relief or convex undulations in the pavement profile. Depending on the speed limits of the road, they have the following dimensions:

a) speed limits not exceeding $50 \mathrm{~km} / \mathrm{h}$ : width $>60 \mathrm{~cm}$, height $<3 \mathrm{~cm}$;

b) speed limits not exceeding $40 \mathrm{~km} / \mathrm{h}$ : width $>90 \mathrm{~cm}$ and height $<5 \mathrm{~cm}$;

c) speed limits not exceeding $30 \mathrm{~km} / \mathrm{h}$ : width $>120 \mathrm{~cm}$, height $<7 \mathrm{~cm}$."

Depending on the speed limit of the road on which you plan to install the humps, the Italian Road Rules guide [7] classifies three different types of humps.

On the roads with speed limits between 40 to $50 \mathrm{~km} / \mathrm{h}$ is allowed the placement of modular prefabricated thermoplastic road humps with very low height. The roads with speed limits between 30 and $40 \mathrm{~km} / \mathrm{h}$ can be equipped with at least $90 \mathrm{~cm}$ wide ridges and no higher than $5 \mathrm{~cm}$; on roads with speed limit not exceeding $30 \mathrm{~km} / \mathrm{h}$, is allowed installation of road humps as high as 7 $\mathrm{cm}$, but their width must be over then $120 \mathrm{~cm}$.

Finally, in case of installation of series, the spacing of each couple of humps must be a value contained in the range from $20 \mathrm{~m}$ to $100 \mathrm{~m}$.

\subsection{Field measurements on road humps}

By the same selection criteria used for the case of RCWs and using the same portable instruments, we have identified 3 sites, of which the characteristics and the observed experimental data are presented in Table 4. 
Table 4: Characteristics and experimental figures of the observed road humps.

\begin{tabular}{|c|c|c|c|c|c|}
\hline Road humps location & $\begin{array}{c}\text { Elements } \\
\text { in series }\end{array}$ & $H[\mathrm{~cm}]$ & $\begin{array}{c}V_{\operatorname{med}} \\
{[\mathrm{km} / \mathrm{h}]}\end{array}$ & $\begin{array}{c}V_{85} \\
{[\mathrm{~km} / \mathrm{h}]}\end{array}$ & $\begin{array}{c}V_{\max } \\
{[\mathrm{km} / \mathrm{h}]}\end{array}$ \\
\hline $\begin{array}{c}\text { Via Pregiuntino (S.Maria } \\
\text { a Monte, Pisa) }\end{array}$ & 1 & 5 & 39.8 & 50.0 & 72.0 \\
\hline $\begin{array}{c}\text { Via Lungomonte (S.Maria } \\
\text { a Monte, Pisa) }\end{array}$ & 3 & 3 & 30.5 & 37.0 & 67.0 \\
\hline $\begin{array}{c}\text { Via Nenni (Vicopisano, } \\
\text { Pisa) }\end{array}$ & 3 & 7 & 32.1 & 42.0 & 73.0 \\
\hline
\end{tabular}

\subsection{Test results}

Even in this case both the efficacy of different types of road hump, and the possible homogeneity of the samples collected was evaluated.

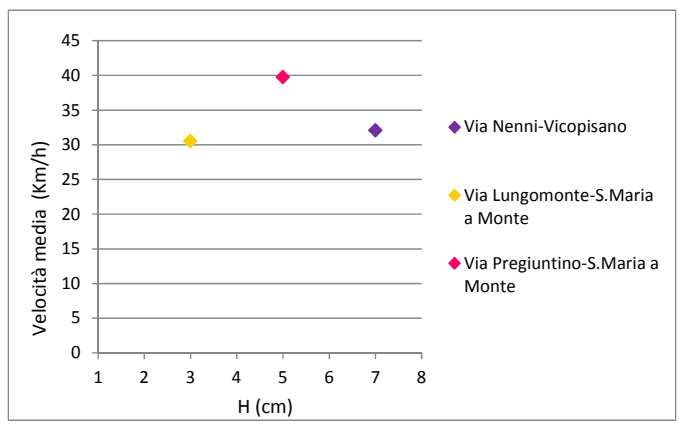

Figure 2: $\quad$ Efficacy of road humps.

Using again the $F$-test, we have obtained the following results of Table 5 where none of the samples was homogeneous, and therefore none of the three different observed types can be considered homogeneous.

Table 5: $\quad F$-Test results on the observed road humps.

\begin{tabular}{|c|c|c|c|c|c|c|}
\hline F-Test & $F$ & $v$ num. & $v$ den. & Fcrit. & $\alpha$ & $H_{0}$ hypothesis \\
\hline $\begin{array}{c}\text { Nenni- } \\
\text { Lungomonte }\end{array}$ & 2.009 & 955 & 345 & 1.161 & 0.05 & rejected \\
\hline $\begin{array}{c}\text { Nenni- } \\
\text { Pregiuntino }\end{array}$ & 1.212 & 2181 & 955 & 1.096 & 0.05 & rejected \\
\hline $\begin{array}{c}\text { Lungomonte- } \\
\text { Pregiuntino }\end{array}$ & 2.450 & 2181 & 345 & 1.149 & 0.05 & rejected \\
\hline
\end{tabular}


Table 6: F-Test results of paired comparison among RCWs and Road Humps.

\begin{tabular}{|c|c|c|c|c|c|c|}
\hline F-Test & $F$ & v num. & $v$ den. & Fcrit. & $\alpha$ & $H_{0}$ hypothesis \\
\hline $\begin{array}{l}\text { Nenni- } \\
\text { Cep }\end{array}$ & 1.445 & 955 & 2090 & 1.094 & 0.05 & rejected \\
\hline $\begin{array}{c}\text { Nenni- } \\
\text { Bonanno }\end{array}$ & 1.175 & 955 & 3555 & 1.089 & 0.05 & rejected \\
\hline $\begin{array}{c}\text { Nenni- } \\
\text { V.Veneto }\end{array}$ & 1.310 & 955 & 2889 & 1.090 & 0.05 & rejected \\
\hline $\begin{array}{l}\text { Nenni- } \\
\text { Bernini }\end{array}$ & 1.661 & 955 & 601 & 1.130 & 0.05 & rejected \\
\hline $\begin{array}{l}\text { Nenni- } \\
\text { Strettoia }\end{array}$ & 1.749 & 955 & 521 & 1.137 & 0.05 & rejected \\
\hline $\begin{array}{c}\text { Nenni- } \\
\text { Cavalletti }\end{array}$ & 1.785 & 955 & 1938 & 1.095 & 0.05 & rejected \\
\hline $\begin{array}{l}\text { Nenni- } \\
\text { Urbiciani }\end{array}$ & 2.027 & 955 & 1065 & 1.109 & 0.05 & rejected \\
\hline $\begin{array}{l}\text { Lungomonte- } \\
\text { Cep }\end{array}$ & 1.399 & 2090 & 345 & 1.149 & 0.05 & rejected \\
\hline $\begin{array}{c}\text { Lungomonte- } \\
\text { Bonanno }\end{array}$ & 1.710 & 3555 & 345 & 1.145 & 0.05 & rejected \\
\hline $\begin{array}{c}\text { Lungomonte- } \\
\text { V.Veneto }\end{array}$ & 1.5332 & 2889 & 345 & 1.146 & 0.05 & rejected \\
\hline $\begin{array}{c}\text { Lungomonte- } \\
\text { Bernini } \\
\end{array}$ & 1.209 & 601 & 345 & 1.173 & 0.05 & rejected \\
\hline $\begin{array}{l}\text { Lungomonte- } \\
\text { Strettoia }\end{array}$ & 1.148 & 521 & 345 & 1.177 & 0.05 & accepted $*$ \\
\hline $\begin{array}{c}\text { Lungomonte- } \\
\text { Cavalletti }\end{array}$ & 1.126 & 1938 & 345 & 1.150 & 0.05 & accepted $*$ \\
\hline $\begin{array}{c}\text { Lungomonte- } \\
\text { Urbiciani }\end{array}$ & 1.009 & 345 & 1065 & 1.152 & 0.05 & accepted* \\
\hline $\begin{array}{l}\text { Pregiuntino- } \\
\text { Cep }\end{array}$ & 1.753 & 2181 & 2090 & 1.074 & 0.05 & rejected \\
\hline $\begin{array}{l}\text { Pregiuntino- } \\
\text { Bonanno }\end{array}$ & 1.433 & 2181 & 3555 & 1.065 & 0.05 & rejected \\
\hline $\begin{array}{l}\text { Pregiuntino- } \\
\text { V.Veneto }\end{array}$ & 1.598 & 2181 & 2889 & 1.068 & 0.05 & rejected \\
\hline $\begin{array}{l}\text { Pregiuntino- } \\
\text { Bernini }\end{array}$ & 2.026 & 2181 & 601 & 1.115 & 0.05 & rejected \\
\hline $\begin{array}{l}\text { Pregiuntino- } \\
\text { Strettoia }\end{array}$ & 2.134 & 2181 & 521 & 1.123 & 0.05 & rejected \\
\hline $\begin{array}{c}\text { Pregiuntino- } \\
\text { Cavalletti }\end{array}$ & 2.177 & 2181 & 1938 & 1.075 & 0.05 & rejected \\
\hline $\begin{array}{c}\text { Pregiuntino- } \\
\text { Urbiciani }\end{array}$ & 2.472 & 2181 & 1065 & 1.092 & 0.05 & rejected \\
\hline
\end{tabular}




\subsection{Comparison of RCWs vs. road humps}

We also compared the speed data of samples measured on RCWs and those measured on a road humps, always using the $F$-test, to investigate an eventual homogeneity of effects between the two types of devices. The results obtained are shown in Table 6 .

As one can see, the road humps used on Via Lungomonte would seem to have the same effect of RCW installed in Via Strettoia, Via Urbiciani and Via Cavalletti. This result, however, cannot be considered valid because the data collected confirm that the speed measured far from the hump and those measured on the hump itself are almost identical, which is justified by the fact that the site of Via Lungomonte is characterized by a reduced width of the road and by a winding road layout, so we can assume that the calming effect is induced by its geometry rather than the device itself, and this is why this sample was previously excluded.

\section{Conclusions}

Close examination of the collected data and above performed analysis lead us to the following conclusions:

a) RCWs with similar geometry and higher heights (i.e. about $15 \mathrm{~cm}$ ) also have the same effect on speed reduction, even if they are placed on roads having different geometry (both in layout and elevation);

b) RCWs with smaller heights (i.e. about $5 \mathrm{~cm}$ ) do not behave like the others: although Via Veneto and Via Bonanno have a similar geometry (and similar are the geometry of the RCWs too); data collected and analyzed through the $F$-Test do not belong to the same population;

c) if on Via Urbiciani was built the third road hump of the series, most likely the sample belonged to the same population of Via Strettoia, Via Bernini, Via dei Cavalletti;

d) the best designed RCW, in terms of speed lowering effect, has been the one observed in Via Urbiciani, with $15 \mathrm{~cm}$ as height and $7.5 \%$ as slope;

e) road humps have greater traffic calming effects than RCW devices.

A series of raised crosswalks seem to have a better performance than an isolated one, and generally the raised crosswalks look to be more effective on speeds than road humps. Nevertheless, further research efforts should be made in order to better evaluate differences between the actual efficacy of raised crosswalks instead of road humps. A more fine-tuned comparison among these traffic calming devices might be also extended to taking into account some of their produced impacts on the environment, such as noise and energy consumption. 


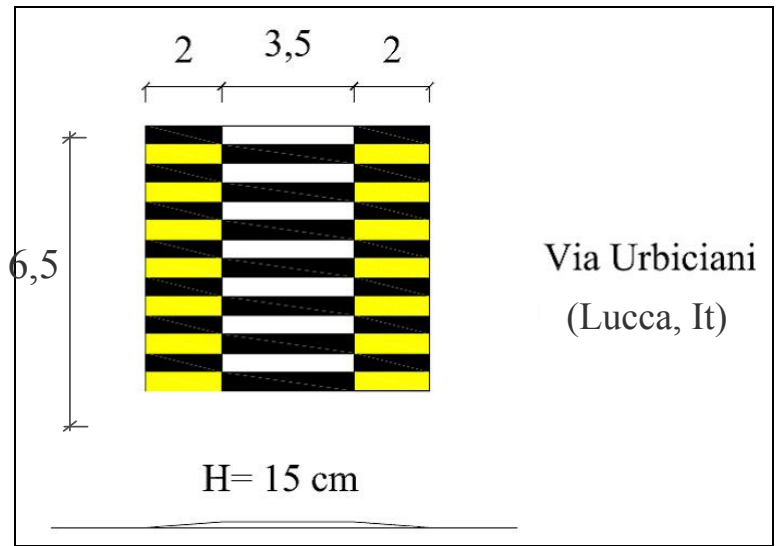

Figure 3: Geometric characteristics of the best designed RCW in terms of its observed efficacy in lowering vehicle speeds.

\section{References}

[1] Busi R. and Zavanella L., Le normative europee per la moderazione del traffico, Vol. III, Edizioni Egaf, Forli' 2006.

[2] Pratelli A., Notes of urban road planning (Annotazioni di viabilità urbana, in Italian), TEP, Pisa 2007.

[3] Hidas P., Weerasekera K. and Dunne M., Negative effect of mid-block speed control devices and their importance in the overall impact of traffic calming on the environment, Transp. Res. Part D, vol. 3, 1998, pp. 41-50.

[4] Ministero dei Trasporti e delle Infrastrutture, Linee guida per la redazione dei piani di sicurezza stradale urbana, Roma 2000.

[5] Pratali R., Studio sugli effetti di moderazione del traffico degli attraversamenti pedonali rialzati, Laurea Thesis, Dept. of Civil Engineering, University of Pisa, 2009.

[6] Crow E.L., Davis F.A. and Maxfield M.W., Statistic Manual, Dover Publications, New York 1960.

[7] Ministero dei Trasporti e delle Infrastrutture, Regolamento di Esecuzione ed Attuazione del Nuovo Codice della Strada (DPR 16 dicembre 1995 n. 495), Roma 1995. 